\title{
Universiteit
}

Leiden

The Netherlands

\section{Early Modern migrants in a language contact setting: characteristics of the Dutch Heusch correspondence (1664-1665)}

Wal, M.J. van der

\section{Citation}

Wal, M. J. van der. (2018). Early Modern migrants in a language contact setting: characteristics of the Dutch Heusch correspondence (1664-1665). Journal Of Historical Sociolinguistics, 4(2), 253-280. doi:10.1515/jhsl-2017-0029

Version: Publisher's Version

License: $\quad$ Creative Commons CC BY-NC-ND 4.0 license

Downloaded from: $\quad$ https://hdl.handle.net/1887/66707

Note: To cite this publication please use the final published version (if applicable). 
Marijke van der Wal*

\title{
Early Modern migrants in a language contact setting: Characteristics of the Dutch Heusch correspondence (1664-1665)
}

https://doi.org/10.1515/jhsl-2017-0029

\begin{abstract}
The present article demonstrates how research on confiscated lateseventeenth-century letters allows us to gain insight into linguistic practices of second and third generations of Dutch-speaking migrants who lived in the German city of Hamburg, in a predominantly Low German region. The historical background of the preserved Heusch correspondence, spoken and written communication in merchant circles, and foreign language learning will be discussed. Apart from examining features such as epistolary formulae, ellipsis, and code switching, the question is also addressed of the degree to which interference from Low (or High) German is found. An analysis of the letters reveals both adoption of the Low German reflexive pronoun sick and a diverse pattern of using the relative particle so, which is shown to be a clear case of adopting (and maybe even extending) a supraregional German relativisation strategy.
\end{abstract}

Keywords: second and third generation migrants, receptive multilingualism, language contact, epistolary formulae, ellipsis, interference, reflexive pronoun, relative particle

\section{Introduction}

In Europe, bilingualism or multilingualism was a normal state of affairs in the past, as has been argued repeatedly (a.o. Schendl 2012). This statement is evident if we take into account the two types of multilingualism which have been characterised as multilingual and multidialectal practices. The first refers to different languages and the second to different varieties within one language. In scholarly discussions, the same distinction is made by the terms external and internal multilingualism (see a.o. Vogl 2012; Kühl and Braunmüller 2014). Early Modern people were indeed well able to communicate across language borders and effectively showed their multiple belonging to different linguistic communities (cf. Burke 2004). Illustrative

*Corresponding author: Marijke van der Wal, Leiden University Centre for Linguistics (LUCL), Leiden, Netherlands, E-mail: m.j.van.der.wal@hum.leidenuniv.nl

Ә Open Access. (c) 2018 van der Wal, published by De Gruyter. (c))BY-NC-ND This work is licensed under the Creative Commons Attribution-NonCommercial-NoDerivatives 4.0 License. 
examples are migrant workers who travelled around Europe and merchants in networks of international trade. The well-known picture of European communication across borders has to a large extent been based on accounts of political contact between nations and on the exchange of ideas within the international literary and scholarly community (cf. Burke 2004). Research has also focused on formal language regulations and on book publishing for a multilingual readership. In these contexts, in which mainly the upper layers of society were involved, Latin and French in particular functioned as linguae francae. Low German played a similar role in the medieval Hanseatic league, i. e. in the domain of trade in which people from various walks of life participated. Although the study of historical multilingualism and language contact is flourishing, what we are still less familiar with, however, are the everyday communication patterns of migrants in the Early Modern period and the survival of their native language in the language contact setting of a foreign environment. ${ }^{1}$

To gain access to part of these as yet less known linguistic practices, we have to be creative in finding appropriate sources and exploring these within the sociohistorical linguistic framework (van der Wal 2016). We also need interdisciplinary information, provided mainly by historians, in order to correctly interpret and explain our linguistic findings. The present article shows how research on confiscated late-seventeenth-century letters allows us to gain insight into linguistic practices of second and third generations of Dutch-speaking migrants who had originally moved from the southern Low Countries to Germany as a consequence of war and religious persecution. Our linguistic material is a collection of 51 Dutch letters, mainly written by Michiel Heusch senior, an influential merchant in the German city of Hamburg, and addressed to his son Michiel junior, who was travelling in Italy on his European grand tour. These letters provide both evidence for the long-term survival of Dutch in a foreign setting and information on foreign language acquisition by young merchants. They allow us to address two issues, which are so to speak two sides of the coin: the survival of Dutch and the characteristics of the Dutch usage involved on the one hand and the influence of a language contact setting on this Dutch usage on the other.

Section 2 introduces the collection of Heusch letters. Section 3 offers more information on the Heusch family and on the contemporary historical background.

\footnotetext{
1 See Rutten et al. (2017) for current issues in the field of historical multilingualism and language contact. Previous studies on communication patterns in the multilingual environment of British regions are Trudgill (2013) (and publications mentioned there) and Joby (2015). Lodge (2014) presents the linguistic experience of a travelling individual in multidialectal France. Publications on the language of migrants within the multidialectal Low Countries are Boyce Hendriks (1998) and Goss (2002).
} 
The linguistic practices and foreign language learning of Early Modern merchants are discussed in Section 4. Sections 5, 6, 7 and 8 focus on characteristics of the Heusch correspondence as an example of Dutch language in exile. In Sections 5 and 6, we examine familiar letter features such as ellipsis and epistolary formulae which are compared with Early Modern Dutch practice. Sections 7 and 8 deal with interference phenomena at both the lexical and syntactical level, in particular with the reflexive pronoun and the relative particle so. Conclusions are presented in Section 9.

\section{A source of confiscated documents}

The seventeenth-century Heusch correspondence (of about 35,000 words in total) covers the period of almost one year, from June 1664 until May 1665. Most of the 51 letters were written by father Michiel Heusch senior, and a few by other family members, i. e. mother Elisabeth Heusch-Bosschaert, sister Elisabeth Heusch, cousin Gerhart Heusch and uncle Jacob Jansen who each wrote a single letter that survived. Michiel Heusch senior maintained his practice of writing to his son every week. He used to send his letters along his son's travel route: at first, to towns in southern Germany (Heidelberg, Nuremberg), and subsequently to the Italian towns of Venice, Bologna, Rome, Naples and Genoa. As his father's future successor in the trading business, Michiel junior made his elaborate tour in order to strengthen the ties of his father's commercial network and to broaden his own experience. Apart from regular advice on both the travel route and Michiel's behaviour, the letters comprise information on business matters such as trading goods and their changing prices, and home news about illnesses, deaths, scandals and the plague.

The Heusch letters are part of the so-called Prize Papers or sailing letters, a unique source of documents, which survived due to European warfare and privateering, the longstanding legitimate activity of conquering enemy ships. In the past this activity was performed by all seafaring European countries and regulated by strict rules. When a ship was taken, all papers on board were confiscated in order to demonstrate that the seized ship indeed belonged to the enemy and was a so-called legal prize. In England, after the legal procedure, the confiscated papers remained in the High Court of Admiralty's Archives (HCA), kept in the National Archives in London (Kew, UK) today. As a result of the frequent warfare between England and the Netherlands from the second half of the seventeenth to the early nineteenth century, approximately 40,000 Dutch letters, both private and commercial, and a wide range of other material survived and are currently stored in over a thousand boxes in the National Archives 
(see van der Wal et.al., 2012; Rutten and van der Wal 2014: 1-2). The confiscated letters belonged to the ships' cargo, as ships sailing to and from the Caribbean, Asia, Africa and European ports often functioned as mail carriers.

The weekly letters sent to Michiel Heusch junior reached him by overland transport (see Figure 1(a) and (b)). However, we owe the one-year collection of letters to his practice of sending the bulk of the received correspondence home by ship. Probably Michiel junior returned mainly his father's letters, which comprised commercial data, for archiving. ${ }^{2}$ One of the

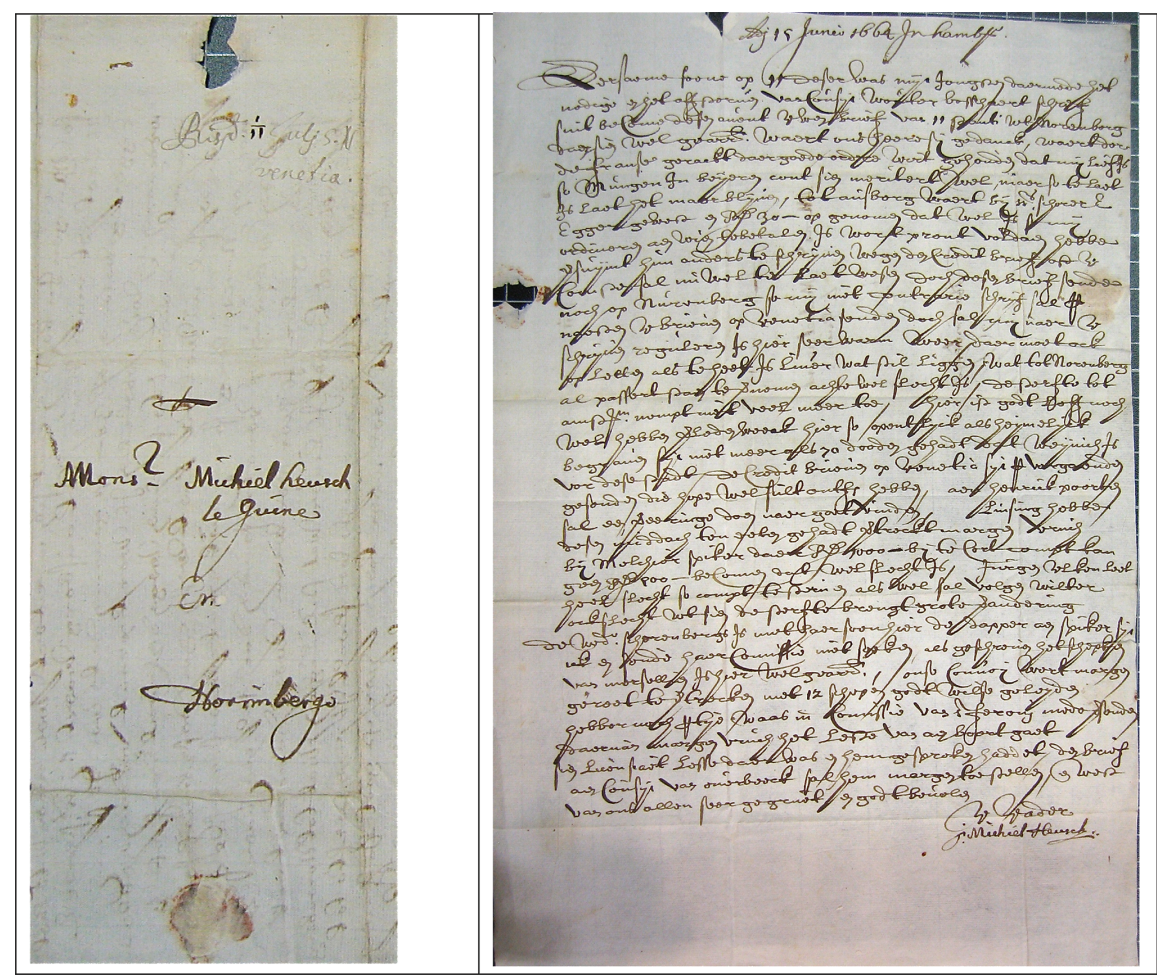

Figure 1: (a \& b) Address and letter by Michiel Heusch senior, dated 15 June $1664^{3}$

2 This would explain why only two letters from his mother and sister survived, whereas a dozen must have been sent (and most probably received) in the one-year period (see also footnote 28). Box HCA 30-223 (National Archives) also contains administrative documents and commercial letters by other correspondents which were sent home by Michiel junior.

3 Above the address (Monsr. Michiel Heusch le jeune En Norimberge 'Mr Michiel Heusch junior in Nuremberg') Michiel junior noted Risp. 1/11 Julj S.N .Venetia 'replied 1 July (old style, i. e. the Julian calendar) /11 July S[tilo] N[uovo] (new style, i. e. the Gregorian calendar) in Venice'. 
letters, dated December 14, 1664, refers to this practice and to a lack of proper care in an earlier case in which ten of his father's letters were returned unbundled, in an open parcel, addressed to the Hamburgian merchant Henrick Poorten. The confiscated Heusch correspondence reveals an extensive network of commercial relations with detailed information of names, preferred trading goods, methods of transport and prices, all of which are valuable data for economic and maritime historians. But the letters themselves are also a treasure trove for historical linguists (cf. van der Wal 2006).

As the confiscated letters preserve the written language of thousands of different writers, men and women, from different social classes, age groups and regions, they form an excellent basis for an investigation of everyday written communication in the past and its variation and change (cf. Elspaß 2012a; Schneider 2013). The first extensive sociolinguistic analysis of these Dutch letters was conducted in the Letters as Loot research programme (2008-2013), funded by the Netherlands Organisation for Scientific Research and directed by Marijke van der Wal at Leiden University (Rutten and van der Wal 2014: 1-18; van der Wal and Rutten 2016). ${ }^{4}$ This research concentrated on a selection of about one thousand Dutch private letters from the late seventeenth and late eighteenth centuries, written by more than 700 different letter writers. Ultimately, the results convincingly proved the great value of the confiscated letters for a monolingual history such as the history of Dutch (for detailed results see the OA Letters as Loot volume, Rutten and van der Wal 2014). The present article will show that the same time-machine-like collection of Prize Papers also allows us to trace linguistic practices and communication patterns of migrants outside the Netherlands, among whom are letter writer Michiel Heusch senior and his family. ${ }^{5}$

4 See also http://www.brievenalsbuit.nl for the Brieven als Buit/ Letters as Loot website, both in Dutch and in English.

5 Some of the Heusch letters are part of our tagged and lemmatised Letters as Loot corpus of 1,000 private letters (amounting to 424,500 words; http://brievenalsbuit.inl.nl), but most of them belong to my additional corpus of another approximately 1,500 transcribed letters which are not yet available online. I gratefully acknowledge the contribution of Hetty Krol, who as a participant in my Wikiscripta Neerlandica transcription project made initial transcriptions of many Heusch letters and also traced genealogical data and the painted portrait of Michiel Heusch senior (see Krol 2011). 


\section{The Heusch family in Hamburg: A migration background}

Historical and genealogical research reveals Michiel Heusch senior's migration background. His father, merchant Peter Heusch (1565-1644), left Antwerp just as many inhabitants did after the fall of Antwerp in 1585, which event ultimately divided the Low Countries into two separate parts, roughly present-day the Netherlands and Belgium. When the flourishing city of Antwerp succumbed to Spanish Catholic rule during the Eighty Years War, non-Catholic inhabitants could choose either to become Catholic or to move to places of free religion. As a consequence, a large number of non-Catholics moved to the northern Low Countries, in particular to towns in the province of Zeeland, to the city of Amsterdam and other towns in the province of Holland, and to Germany, to commercial centres such as Hamburg, Cologne and Frankfurt. The Eighty Years War and freedom of religion were thus the reasons for a substantial migration of Dutch-speaking Flemings and French-speaking Walloons from the southern Low Countries to the Netherlands and Germany (cf. Asaert 2010 and literature mentioned there).

Protestant people from various social ranks found refuge in the city of Hamburg, both the poor working class as is evident from the poor relief (Armenkasse) documents (Asaert 2010: 91-92) and rich merchants, who could easily transfer their commercial activities due to the transition period of four years granted to non-Catholics in Antwerp (Asaert 2010: 39-41). ${ }^{6}$ The social rank of foreign merchants in Hamburg society, and that of the Heusch family in particular, was definitely high as is shown by evidence from historians. In 1619, Peter Heusch appeared to be one of the richer merchants and his son Michiel Heusch senior was no less successful. ${ }^{7}$ His network of trading partners extended to Russia, England, France, Italy, Portugal and Spain (Reißmann 1975: 38). In a recent study, Michiel Heusch is characterised as the Hamburg merchant with the largest network of thirteen European ports (Lisbon, Porto, Sanlúcar, Cádiz, Málaga, San Sebastián, London, Rouen, Marseille, Genoa,

6 See also Schaser (1995) for the various social groups of migrants and Hamburg's approach of immigrants ("Fremdenpolitik als Wirtschaftspolitik"). Lindberg (2008) argues that openness towards foreign merchants was favourable for Hamburg's rise as a metropolis of international trade.

7 In 1619, Peter Heusch, involved in Hamburg's Iberian trade, was, with a banking turnover of over 100,000 Mark, among the 42 big businessmen (Baumann 1990: 260-261). In 1645, Michiel Heusch senior's overseas trade amounted to over 200,000 Mark, the largest turnover among 481 Hamburg merchants involved in overseas trade (Reißmann 1975: 35; 379-384). 
Venice, Sicily and Gdańsk/Danzig) in 1647 (Poettering 2013: 219-220). Products bought and sold were Russian leather, salt, metal, wax and wheat from Germany and Scandinavia, wool from England, rice, wine, currants, almonds, silk, oil, and lemons from the Mediterranean.

The influx of migrants had major demographic consequences for the city of Hamburg. According to estimations, in 1600 approximately a quarter of the Hamburg population of 40,000 inhabitants consisted of migrants from the southern Low Countries (Waley 2002: 9; Uppenkamp 2015: 61-62). Many of them lived in the relatively new southern city quarter, in streets such as Wandrahm and Holländischer Brook. They had their own institutions including the previously mentioned Armenkasse, societies and religious meetings (Van Roosbroeck 1968: 245-271). In the Dutch-speaking merchant circles of Hamburg, endogamy was an evident practice. ${ }^{8}$ Peter Heusch married Marie van Meere(n) (1570-1603), member of a merchant family from Antwerp, and in 1633 their third son, letter writer Michiel Heusch, also married a woman from a merchant family with Antwerp roots, Elisabeth Bosschaert, daughter of Melchior Bosschaert (1573-1623) and Elisabeth Harbarts (1584-1664). ${ }^{9}$ We may conclude that Michiel Heusch senior (1601-1684) and his wife Elisabeth Bosschaert (1609-1679) were both born and raised in Hamburg. They were second-generation migrants in present-day terms and their children, their son Michiel, the addressee of the letters, and their four daughters, Elisabeth, Anna, Suzanna and Catharina, were third-generation migrants.

Living in particular city quarters and preferring endogamy suggest segregation, but at the same time evidence of perfect integration is found in the case of Michiel Heusch senior. As a wealthy and influential merchant, he was elected the first president of the Commerzdeputation, the precursor of the Chamber of Commerce, on January 19, 1665, which was a prominent task to fulfill (Handelskammer Hamburg 2015: 10-11, 14-15). From the letters sent to his son on 18 and 25 January, it appears that Michiel initially did not intend to accept the membership or the presidency of this body of six merchant representatives, but ultimately he had to accept in order to avoid being hated ("om niet gehaedt te worden”, letter dated March 1, 1665). Two other merchants, however, were given the task of setting out for England to negotiate free trade during the Second Anglo-Dutch War (1665-1667). Apparently, Michiel succeeded in refusing that

8 On endogamy in Hamburg see also Poettering (2013: 261-262, 317).

9 For genealogical data of the Heusch family see Fürth (1890, vol. 1, 2 ${ }^{\text {e }}$ Appendix Zur Genealogie einzelner Aachener Familien, 12-13) and with corrected data for Heusch senior: http: hamburgerpersoenlichkeiten.de. For the Bosschaert family see http://www.bosschaerts. be/genealogy/getperson.php?personID=I8406\&tree=W1-bosschaerts 
task, but he still reports on the important mission and expected outcome in seven other letters (15 February, 1, 8, 15, 22 March, 19, April 26, 1665).

A portrait painted by well-known Dutch painter Bartholomeus van der Helst (1613-1670), shows Michiel Heusch as an impressive, self-confident man with a letter in his left hand, addressed Al sig. (=Al signore) Michiel Heusch in Hamborgh 'to Mr Michiel Heusch in Hamburg' (Figure 2). ${ }^{10}$ He clearly belonged to a group of prestigious merchants in Hamburg, operating in an international network, but what did this position mean in linguistic terms? What was the

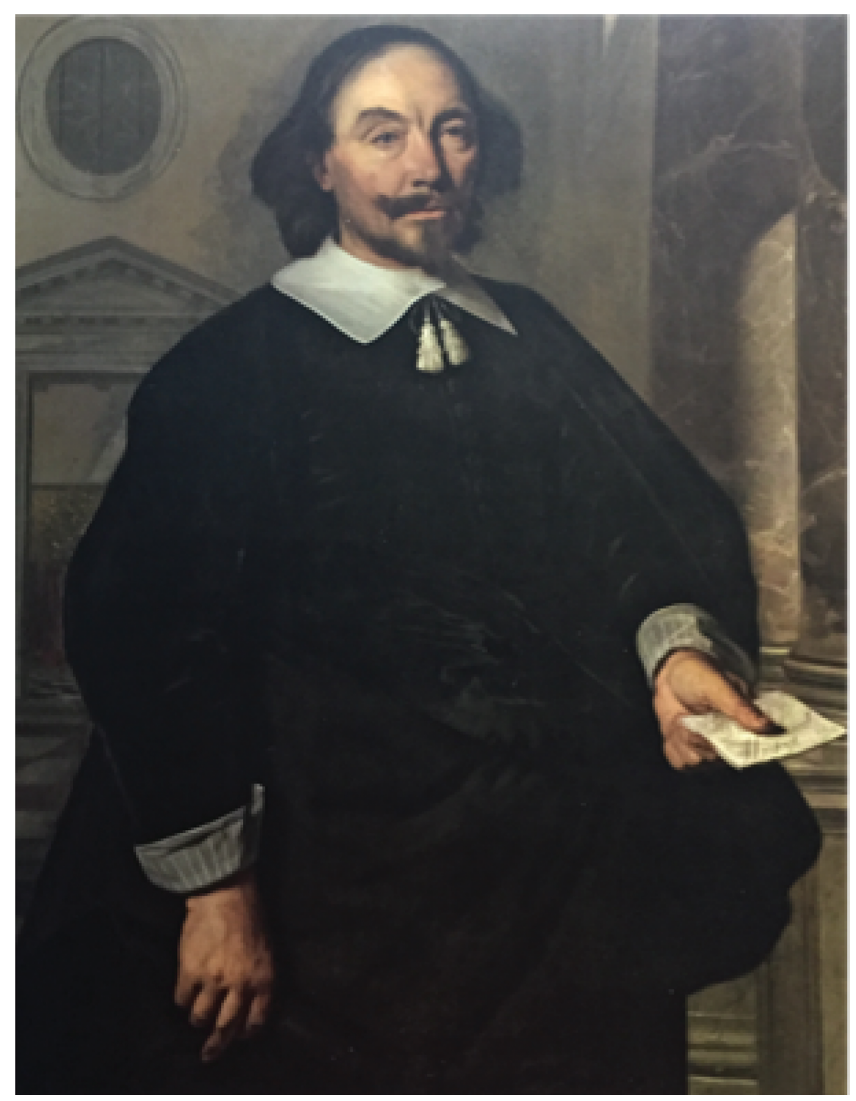

Figure 2: Portrait of Michiel Heusch senior by Bartholomeus van der Helst.

10 The painting is kept in the Philadelphia Museum of Art, Collection John G. Johnson, nr. 495, www.Philamuseum.org. Cf. Johnson et al. (1913: vol. 2: 93, 341) and Handelskammer Hamburg (2015: 10-11, 14-15). 
linguistic impact of living in Dutch- and Low German-speaking circles and participating in an international, multilingual network ${ }^{11}$

\section{Merchants and their linguistic practices: Communication and foreign language learning}

Flemish merchants dominated trade in Hamburg. ${ }^{12}$ They preferred endogamy and continued to speak Dutch for generations. Historians even argue that "Dutch was the language spoken at the Hamburg stock exchange” (Uppenkamp 2015: 62) and that Dutch functioned as a lingua franca among merchants in Hamburg (Poettering 2013: 168). In my opinion, however, this is too hasty a conclusion based on a contemporary comment by a German-Danish traveller who notes that High German is little used in Hamburg and that at the stock exchange a mixture of Low German and Dutch is used. ${ }^{13}$ This practice is exactly what could be expected in the Low German area to which Hamburg belongs. More in detail, we expect that so-called receptive $b i$ - or multilingualism, described by Braunmüller for the Scandinavian area during the Hanseatic League, must also have been a frequent phenomenon in seventeenth-century Hamburg (Braunmüller 1997, Braunmüller 2007, Braunmüller 2013). In face-to-face communication, which is an essential characteristic of receptive multilingualism, Dutch-speaking and Low Germanspeaking merchants must have been able to deal with all their business matters in their closely-related languages. ${ }^{14}$

Receptive multilingualism overcomes communicative problems of speaking, but what was the writing practice? Among the confiscated Prize Papers, lateseventeenth-century letters written in Low German were discovered, which evidence corrects a textbook opinion on the lost written language function of Low German at that time (cf. Elspaß and Stolberg 2014). How widespread this Low German writing practice was is still a matter of further research. Merchants

11 The actual linguistic situation may have been even more complicated, as French-speaking Walloons also belonged to the so-called nation of people originating from the Low Countries in Hamburg.

12 I use the term 'Flemish' to indicate Dutch-speaking people from the southern Low Countries. 13 According to Kunrat von Hövelen, Hamburgs Hoheit, p. 132, "die ädele hoch-deutsche Heldensprache" was little used, as "die Kaufbursche (um Das Sie in Holland gereiset und auch Brabander, Holländer, Englische und dergl. Vile in Hamburg Säshaft) Niderdeutsch gebrauchen und Holländisch meist untermischen". Poettering (2013: 168) concludes: "Die Sprache der Niederländer hatte unter den Kaufleuten in Hamburg den Status einer lingua franca".

14 For features of receptive multilingualism see Braunmüller (2007: 29-32). 
with Flemish (or Dutch) roots, however, had another choice for their written communication: the choice found in the Heusch correspondence, which testifies to the survival of written Dutch up till the third generation of migrants, that is the generation of Michiel Heusch junior and his sisters. For them, Dutch was still a home language and a written language for communication with relatives and trading partners. ${ }^{15}$

Merchants operating in an international network needed to know their foreign languages. Learning these languages abroad was common practice for sons of internationally trading merchants and young men belonging to the upper levels of society, who often made a grand tour to broaden their horizons. ${ }^{16}$ It is not surprising, therefore, that father Heusch's letters repeatedly stress the importance of speaking Italian fluently and of acquiring good writing competence: ondertussen hope Uwen tijt wel aenlegt om het Italians wel te leren spreken en schrijven, 'in the meantime I hope that you use your time well in order to learn both speaking and writing Italian well'. ${ }^{17}$ Apart from relying on an Italian teacher, copying letters is considered a highly recommended learning method. ${ }^{18}$ Progress in speaking Italian is important for building a network during Michiel's tour abroad, whereas writing experience will be useful for answering Italian letters on his return home. ${ }^{19}$ Italy is not the end of Michiel's journey: he plans to leave for France, and again foreign language learning is an important issue. He has to consider which is the most suitable place for learning French: either Geneva or Orleans. The latter is close to Paris where, according to his father's information, good French is spoken. ${ }^{20}$

15 Commercial letters by other correspondents such as Pauell Pell, found in Box HCA 30-223 (National Archives), show that Dutch was the language of written communication with both relatives and trading partners.

16 In 1680, young Johann Schulte travelled from Hamburg to Lisbon in order to learn Portuguese and build his own trading network (Poettering 2013: 167). Just like Michiel Heusch, he regularly received letters from his father. See Merck (1856) for these German letters. 17 Letter 47, dated April 26, 1665. See similar advice in letter 6, dated July 6, 1664 and letter 45, dated April 12, 1665.

18 See letter 21, dated November 9, 1664, in which Michiel senior comments on his son's activities in Rome. Apparently Michiel junior was visiting the sights and used to have a language teacher in the morning. His father remarks: het schrijven sal $U$ wel nut worden, schrijft so wat brieven uut daer leert men best bij 'the writing [of Italian] will be useful for you; copy a few letters; one learns most from this/ this is the best way of learning'.

19 The importance of speaking Italian with the business partners Michiel junior meets is stressed in letter 25, dated December 7, 1664, and letter 33, dated January 25, 1665. The remark on answering Italian letters is made in letter 40, dated March 15, 1665.

20 See letter 35, dated February 15, 1665 in which Heusch senior refers to his son's travel plan and mentions Orleans as an alternative for Geneva. 
Linguistically, the collection of Heusch letters reveals the preservation of Dutch up to the third generation of migrants. This long-term survival of Dutch occurred in favourable circumstances of a large community with joint roots and the practice of endogamy, but did the non-native, Low German context have any influence on the Dutch language used? The questions arise of whether we find any interference from Low (or High) German or any code switching in this setting of language contact. We will deal with these questions in Sections 7 and 8, after having focused on two characteristics of the correspondence: the striking feature of ellipsis in Heusch senior's letters (Section 5) and epistolary formulae used by the five individual letter writers (Section 6).

\section{Familiar letter features and beyond: Ellipsis}

Ellipsis of the first person singular or plural as subject is a common feature in letters, diaries and ship's journals, as the writing subject is evident. Most of the letters written by Michiel Heusch senior, however, show not only a frequent first person subject ellipsis such as become 'I receive', verneme 'I understand', but also second person ellipsis or ellipsis of the addressee such as daer (...) wel gearriveert waert 'where you had arrived safely', Dacht 'you intended' in (1):

(1) Eersaeme soene, op 28 pass[ato] was mijnen jongsten. Sint become nu van avent uwen brief van 27 pass[ato] uut Heidelberg, daer verneme wel gearr [iveert] waert. (...) Dacht dien dach nog per Strasborg te vertrecken. ${ }^{21}$

'Worthy son, on the $28^{\text {th }}$ of the past month (=28 May) I sent my most recent letter. This evening I receive your letter dated 27 May from Heidelberg, where I understand that you had arrived safely. You intended to leave for Strasbourg that day' (letter 1, dated 4 June 1664)

In passing we note the ellipsis of the conjunction dat 'that', which is another familiar feature in contemporary letters. On closer inspection, Heusch senior consistently omits the second person pronoun subject forms; only one instance of an explicit addressee occurs:

21 The full forms of abbreviations such as pass and gearr are indicated with square brackets, punctuation was added and minor orthographic adaptations made in this and all following examples from the Heusch correspondence. 
(2) Schrijve hem so ghij daer bent dat alles met $u$ in raet sal stellen 'I will write him [= Lanckhorst] that he has to consult you in everything as soon as you are there' (letter 29, dated January 4, 1665)

The pronoun ghij/ghy 'you' is the regular form of address used by the female letter writers, of whom only mother Elisabeth shows one instance of addressee ellipsis. ${ }^{22}$ Father, mother and sister all use $u$ as oblique 'you' and possessive form 'your'; the possessive pronoun uw 'your' does not occur. Cousin Gerhart and uncle Jacob Jansen, however, use the epistolary form of address $u l$, the most frequent epistolary form in late-seventeenth-century letters, without any instance of the rising epistolary variant ue 'your honour'. ${ }^{23} \mathrm{Ul}$, the abbreviation of uwe liefde/u liefde 'your love, your kindness', occurs in all instances as subject, oblique and possessive form as is shown in (3). ${ }^{24}$ Addressee ellipsis is not found in their letters.

(3) Overmits wij verstaen dat ul nu tot Genoa sal comen, en aldaar ongetwijffelt de affaires van ul oom sal[iger] sterfhuijs met de ss ${ }^{\circ}$. Viganega en Schepel vereffen, oversulx nemen de vrijhijt ul oock met onse commissie te bemoijen 'As we understand that you will come to Genoa now and will undoubtedly arrange the business of your late uncle's bequeathed estate with Messrs Viganega and Schepel, therefore we also take the liberty of bothering you with our commission' (letter 37, dated February 22, 1665, cousin Gerhart Heusch)

Michiel Heusch senior's habit of frequently omitting items sometimes even extends to third person pronoun ellipsis such as in (4):

(4) Een van dees Selms soen, die noch jongman was, is vor 2 dagen overleden. Men seijde vor desen dat met de jongfrou Rodenbergs verloeft was, so verleden jaer stirf bijden borgemester; sijn malcanderen haest gevolgt 'One of this Selm's sons, who was still a bachelor, died two days ago. One said that he was previously engaged to maiden Rodenbergs, who died last year at the mayor's; they have followed one another swiftly' (letter 2, dated June 8, 1664)

22 In mother Elisabeth's letter we find twice ghij and once ellipsis. In sister Elisabeth's letter ghy occurs twice.

23 For the various forms of address see Rutten and van der Wal (2014: Ch. 6, 203-245).

24 A single instance of $u l$ as oblique form is found in Heusch senior's letter 7, dated July 7, 1664: Tis vremt $s^{r}$ Druijvesteijn ul niet wat assisteert 'It is curious that Mr Druijvesteijn does not help you a bit'. 
Interpreting the letters, you have to pay attention to these frequent instances of ellipsis which appear in the weekly letters by Heusch senior and may be characterised as conversational deletion, a phenomenon of both spoken language and particular genres of written language. ${ }^{25}$

Michiel Heusch's consistent ellipsis of the second person pronoun and his irregular third person pronoun ellipsis are prominent features of his correspondence. This phenomenon seems an individual characteristic, as, apart from one instance (see footnote 22), these features do not occur in letters by the other relatives or in other private correspondence with which we are familiar. Whether the extension of the first person pronoun ellipsis is to be found in an elaborate corpus of contemporary business letters remains a suggestion for further research. What the ellipsis case furthermore shows is variation in the usage of Dutch migrants abroad. They vary in their forms of address: usage of ghij/ghy 'you' by the two female letter writers and of ul by the two male writers, both familiar variants in a non-migrant Dutch setting. Inter-individual variation will also be examined, when turning to epistolary formulae in the next section.

\section{Epistolary formulae: Variation in opening and closing of a letter}

Early Modern letter writers were familiar with epistolary formulae: prefabricated chunks of language, which have been similar in many European languages for centuries (cf. Elspaß 2012b; Rutten and van der Wal 2014: 75-128). These formulae fulfill text-constitutive, intersubjective and Christian/ritual functions. For the Heusch correspondence, I will focus on the opening and the closing of the letters, where various such formulae occur.

The openings clearly show text-type formulae, a subtype of text-constitutive formulae, which identify the text as a letter. The date and the writer's location are followed by one of the options for addressing the recipient according to the following pattern in Michiel Heusch senior's letters (5):

25 See Thrasher (1974) for an early study of what was termed conversational deletion in American English. 
(5) [the date] [the place] [the addressee]

Adi $^{26} 4$ Junio 1664 In Hamborch, Eersaeme soen/ Lieve soene/ Eersaeme lieve soene

'On the day of June 4, 1664 in Hamburg, worthy son/ beloved son/ worthy beloved son'

Whereas slight differences in date and place occur, addressing the recipient not only varies on behalf of a different relationship. Both uncle Jacob Jansen (6) and cousin Gerhart Heusch (7) address Michiel junior in French:

(6) $A^{o} 1665$ adi 8 feb $^{\text {ra }}$ Hamborch - Mon Cousijn

'Anno 1665 on the day of 8 February Hamburg - My nephew' (letter 49)

(7) Hamb. 22 Febr. 1665. Monsieur et Cousin

'Hamburg February 22, 1665. Sir and cousin' (letter 37)

Gerhart Heusch continues with a greeting the recipient formula:

(8) Naer salutatie, hebben van ul heer Vaeder ul goede dispositie seer geerne vernomen

'after greeting, we have understood with pleasure your good health from your father' (letter 37, cousin Gerhart Heusch)

Naer salutatie 'after greeting' is immediately followed by mentioning that the letter writer was informed of the addressee's good health by father Heusch. This remark replaces the familiar intersubjective health formula, which confirms the writer's own good health and expresses health wishes for the addressee (Rutten and van der Wal 2014: 114-121). Michiel junior's sister Elisabeth uses the similar greeting formula, albeit with the Dutch noun groetenis 'greeting' instead of the French loan salutatie (Rutten and van der Wal 2014: 100-101). The self-reference formula dient desen 'this letter serves' follows:

(9) Anno 1665 Den 5 April in Hamborch. Lieven Broeder naer vriendelycke groetenis dient desen...

'Anno 16655 April in Hamburg. Dear brother, after friendly greeting this letter serves...' (letter 44, sister Elisabeth Heusch)

26 Adi, ady, adij originate from Latin a die 'on the day', which Latin phrase is also found in contemporary letters. 
Both the greeting formula and the self-reference formula are found in the lateseventeenth-century private letters of the Letters as Loot corpus. These letters also often contain a praise to God element which preceeds the location and date. Among the Heusch correspondents, however, mother Elisabeth is the only one who uses the frequent Praise God in the town of... formula ${ }^{27}$ :

(10) Looft God altijt In Hamborch adij 26 appril 1665

'Praise God always in Hamburg on the day of April 26, 1665' (letter 48, mother Elisabeth Heusch)

We thus find various familiar conventions and, moreover, we notice the differences between the letters by uncle and cousin with French features and those by father, sister and mother.

After having addressed his son, father Heusch follows a consistent opening pattern of referring to their earlier communication. He mentions the date of his previous letter, followed by reference to the latest letter he received from his son and its contents. For example:

(11) Eersame soene, op 31 pass[ato] was mijnen jongsten. Sint become uwen aeng [enaemen] van 29 pass[ato]. Daeruut gern gesien den brief per Napoli aen sr. Van Dal ontfangen haddet.

'Worthy son, on the 31st of the past month (=31 August) I sent my most recent letter. Since I receive/ received your pleasant letter of 29 August. From this letter I learnt with pleasure that you had received the letter sent to Naples to Mr. Van Dal' (letter 13, dated September 7, 1664)

This practice was useful for the correspondents and it also informs us about missing letters in the preserved correspondence. ${ }^{28}$

The closing of Michiel Heusch's letters shows some variation, as he uses three types of intersubjective greeting formulae, combined with a commendation formula. His most frequent greeting formula (34 instances, $74 \%$ ) consists of an imperative of the verb sijn 'to be' plus the participle gegruet/gegroet/gegruut 'greeted' which is often modified by hartelyck/van harten/seer 'heartily, from the heart, very' as in (12). The optional elements are indicated in square brackets, the greeting and commendation formulae in bold. The option In gnaden shows German interference.

27 This appears to be a typical seventeenth-century formula: 260 hits are found in 595 seventeenth-century letters and only one eighteenth-century hit in 438 eighteenth-century letters of the Letters as Loot corpus. See also Rutten and van der Wal (2014: 93-97).

28 Five of Heusch senior's letters, four letters by mother Elisabeth, four by sister Elisabeth, three by sister Anna and one by any of Michiel's sisters appear to be missing. 
(12) West [hiermede] [van ons allen/tsamen/ van moeder en ons allen/ van moeder U susters ende mij][hartelyck/ van harten/ seer/] gegruet en den heere/ godt [allmachtich] [In gnaden/In genaden/ In sijn heijlige bescherminge] bevolen

'Be with this from all of us /together/ from mother and all of us/ from mother, your sisters and me heartily/ from the heart/ very greeted and recommended to the Lord/God almighty in mercy/in his holy protection'

Alternatives are a combination of the verbs doen 'to do' and grueten/gruten 'to greet' (see (13); 5 instances, $11 \%$ ), often modified by seer/hartelyck 'very/heartily', and the noun phrase of the preposition naer 'after' and the noun grutenis 'greeting' (see (14); 7 instances, 15\%), which noun phrase also occurs at the opening of letters as discussed above:

(13) Doen U[tsamen] [seer/hartelyck] grueten ende west den [allmogende] Heer[e] bevolen....

'We together greet you very/ heartily and be recommended to the almighty Lord...'

(14) west naer grutenis [van ons allen] den Heere bevolen

'After greeting from all of us be recommended to the Lord'

Mother Elisabeth combines the 'greeted' option with the 'to do' variant:

(15) U susters doen $\boldsymbol{u}$ vrindelijck groeten (...) ende zijt van mij hartlijck gegroet ende Godt in genaden bevolen tot langer bestendigher gesontheijt 'Your sisters greet you friendly (...) and be greeted heartily from me and be recommended to God in mercy in order to have a longer steady health' (letter 48, mother Elisabeth Heusch)

The other letter writers use only the alternative patterns: sister Elisabeth and uncle Jacob Jansen, the 'to do' pattern and cousin Gerhart Heusch, the 'after greeting' pattern naer cordiale groetenis, with the French loan equivalent of hartelyck 'heartily'. ${ }^{29}$ In only one of Michiel senior's letters, letter 23, dated November 23, 1664, is the greeting formula lacking. The commendation formula west den Heere bevolen 'be (re)commended to the Lord' is present in all 51 letters

29 Taking into account the other correspondents, the percentages of the three types of formulae are $69 \%$ (35 instances), 16\% (8 instances) and 16\% (8 instances) respectively across the whole correspondence. 
of the Heusch correspondence. This formula shows some phrasal and lexical variation such as 'be recommended to God/the Lord/the almighty God/the protection of the Lord etc.' which is also found in other seventeenth-century letters (see Rutten and van der Wal 2014: 125-127).

These few examples of formulaic language show that second and third generation migrants were familiar with Dutch epistolary formulae and their variants. The opening and closing formulae of their letters do not deviate from the Dutch epistolary formulae found in late-seventeenth-century private letters and shared with German and other European languages (cf. Elspaß 2012b; Rutten and van der Wal 2014: 75-128). Moreover, we found both variation in the formulae and some inter-individual variation which illustrate a still good command of varied written Dutch. Whether and to which degree this varied written Dutch was influenced by the language contact setting, our second issue, will be examined in the following sections. It is not only at the level of lexical items, such as illustrated by gnaden above, and the reflexive pronoun, but also at the syntactical level of a relative clause pattern that German interference can be traced as will be shown in Sections 7 and 8 respectively.

\section{Interference at the lexical level and the reflexive case}

In a language contact setting lexical interference may be expected, which does occur, although not to a high degree, in the Heusch letters. Apart from variation in pairs such as gnade(n)/genade(n) 'mercy', plats/plaets 'place', ${ }^{30}$ we find only the lexical items herbst, osteren, pingsten, arnte, lorberen, stockfisch, erholden 'autumn, easter, pentecost, harvest, laurel-berries, stockfish, to keep alive'. All instances of Low or High German interference occur in Heusch senior's letters apart from a single pinghsten in mother Elisabeth's letter and future werden used by sister Elisabeth: ${ }^{31}$

(16) groetmoeder (...) sal den herbst wel niet aff leven

'grandmother will probably not survive the autumn (letter 6, July 6, 1664; a second example of herbst in letter 7, July 13, 1664)

30 Gnade(n) occurs twice in Heusch senior's letters versus two instances of Dutch genade(n). Plats (6 instances) and platsen (2 instances) occur versus only two instances of Dutch plaets (2) in letters written by Heusch senior.

31 Apart from High German herbst, all lexical items are either Low German (arnte, pingsten, erholden) or identical in Low and High German (gnade, plats, osteren, lorberen, stockfisch). 
(17) Soet Godt belieft op Osteren sullen eens veranderen

'if it pleases God, we will change/ move at Easter' (letter 23, November 23, 1664; a second example in letter 14, September 14, 1664)

(18) Inde weeck vor pingsten

'In the week before Pentecost' (letter 43, April 5, 1665; a second example, pinghsten, in mother Elisabeth's letter, i. e. letter 48, April 26, 1665)

(19) hier hebben nu veel regen, dat niet goet vor de arnte is 'here we have much rain now, which is not good for the harvest' (letter 8, July 20, 1664)

(20) desen morgen is een schip van Portaport gearr[iveert], brengt over hondert

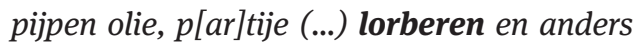

'this morning a ship arrived from Oporto, it brings over hundred casks of oil, a delivery of laurel-berries and other goods' (letter 47, April 26, 1665)

(21) van stockfisch is niet abondant

'stockfish is not abundant' (letter 10, August 3, 1664)

(22) Godt wil haer erholden

'God may keep her alive' (letter 8, July 20, 1664)

The item erholden is the most frequent one: apart from (22), five other instances occur, all in a similar formula with the following pattern of four elements (the optional elements are indicated in square brackets):

(23) Godt/ Ons Heere (1) wil (2) haer/hem/se (3) [noch/ vorder] [in gesondtheit] erholden (4)

'God/ Our Lord will her/him/them still/further in health keep alive'

Furthermore, het geeft, the calque of es gibt, occurs (24) and the verb worden is used to indicate future, which is current in German, but not in Dutch (25):

(24) het wil eenen bloedigen oorloch geven

'a bloody war will happen' (letter 39, March 8, 1665) 32

32 Other examples are: So wilt daer slechte negotie geven 'Then there will be bad trade there' (letter 30, January 11, 1665); hope goede negotie sal geven 'I hope that there will be good trade' (letter 28, December 28, 1664). 
(25) of Vader se hem nu noch af eyssen wort weet ick niet

'I do not know whether Father will still demand them from him' (letter 44, April 5, 1665, sister Elisabeth) ${ }^{33}$

An interesting case is the reflexive pronoun. In Dutch the personal pronoun originally functioned as a reflexive third person singular and plural, but in the seventeenth century the reflexive pronoun zich became an increasing alternative. For example, 'to wash oneself' could be indicated by either the old option hem/haer wassen or the newer option zich/sich wassen. Stressing the importance of a separate reflexive pronoun, the Dutch grammarian Petrus Leupenius preferred the Low German variant sik to High German and Dutch sich/sig/zich in his grammar of 1653, but sik/sick did not gain ground in Dutch (van der Wal 1992: 125-127). What is striking in the Heusch correspondence is that we find fourteen instances of the Low German reflexive sick as opposed to eleven of the old option, and not a single instance of Dutch or High German sich/sig. See the following examples:

(26) my sal lief sijn den barbier gesel hem wel draegt

'I shall be pleased that the surgeon's/ barber's apprentice will behave himself well' (letter 1, June 4, 1664)

(27) De wed[uw]e heeft qualijck gedaen niet van haer geseijt heeft

'The widow did wrong by not telling about herself' (letter 14, September 14, 1664)

(28) hope sal sick als een knecht behoort comporteren

'I hope that [he] will behave himself as a servant should' (letter 1, June 4, 1664)

(29) Daerop set sick opt peert

lit. Then he put himself on the horse/ Then he mounted the horse (letter 39, March 8, 1665)

In this case, the Low German variant of the Hamburg environment was clearly adopted by Michiel Heusch senior whose letters comprise all reflexive

33 Another example is de flesse voeders worden morgen aen boort gaen 'the cargo of bottles will be loaded aboard tomorrow' (letter 20, November 2, 1664). 
instances. ${ }^{34}$ Looking more closely at the fourteen sick instances, we notice a few cases of additional interference apart from the sick form itself: ${ }^{35}$

(30) Cattarina sal met eersten een briefken schrijven en sick bedancken 'Cattarina will write a letter soon to thank you' (German sick/ sich bedanken versus Dutch bedanken; letter 23, November 23, 1664)

(31) dat sal so veel niet op sick hebben 'that will not mean much' (German das hat nichts auf sich; letter 26, December 14, 1664)

(32) en willen sick roepen met den degen 'and they will challenge one another to a duel' (reciprocal usage of sick/ sich in German; letter 39, March 8, 1665)

These instances show not only adoption of the sick pronoun, but also interference by German syntactical patterns and idiom. A similar instance of syntactical interference is found in the reflexive use of the personal pronoun hun (33):

(33) Ende sss. Moens antworde heeden en bedancke hun vor hun presentatie 'And Messrs. Moens reply now and they thank for their gift' (letter 10, August 3, 1664, Heusch senior)

\section{A syntactical pattern: so in relative clauses}

The Heusch correspondence shows yet another striking characteristic: single so not only functions as a conditional subjunction or as a resumptive element (34), but also as a relative particle (35).

(34) So noch in tijts compt, so spreck tot Napels $s^{r}$. Gio d'Nafro Giordani eens aen 'If you come in time, (then) address Mr. Gio d'Nafro Giordani in Naples' (letter 18, 19 October 1664, Heusch senior)

34 The letters by the four other correspondents do not comprise any reflexives, which are a low-frequent phenomenon in letters. Due to this low frequency, it also proved difficult to present conclusive evidence in the linguistic discussion of the origin, spread and distribution of Dutch zich (see Nobels 2013: 115-121).

35 I thank prof. dr Ann Marynissen (University of Cologne) for drawing my attention to the possibility of additional interference. 
(35) Men wil hier veel seggen van mr. Frans Townleij sijn soen, so tegenwordich in Italien is en daer wel sult gesproken hebben

There are many rumours about Mr. Frans Townley's son, who is in Italy at present and with [whom] you may have spoken there (letter 24, November 30, 1664, Heusch senior)

The invariable relative particle so, which occurs in 41 instances in only Michiel Heusch's letters, is not a feature of Dutch (Dutch relativisers are die, dat, wie, wat, welk and hetgeen). ${ }^{36}$ It does occur as a supraregional relativisation strategy in German, but only in a particular period, mainly from the second half of the fifteenth until the late seventeenth century, declining in the eighteenth century, and alongside the familiar system of relative pronouns (der, die, das), derived from the demonstrative pronoun, and welch- (see Behaghel 1928: 729-732; Ebert 1986: 163, Ebert 1993: 447-448; Ágel 2010; Dal 2014 [1962]: 236-245). Originally, so was used mainly in administrative documents, but from the early sixteenth century onwards this usage expanded to, for instance, letters and sermons, and later to epic prose (Ebert 1993: 447). The relative particle so would usually occur as subject or direct object (Ágel 2010: 201-203) and mainly in restrictive relative clauses immediately after the antecedent (Ebert 1993: 447). Analysing the instances in the Heusch correspondence, however, we find a more diverse pattern, which varies depending on the animacy or inanimacy of the antecedent. With animate antecedents, so functions as a subject in only appositive clauses, both embedded (so immediately follows the antecedent) (36) and final appositive clauses (with one or more elements between the antecedent and so) (37):

(36) $\boldsymbol{S}^{\boldsymbol{r}}$. Johan Behn, so met u naer Leibsich reijsde, is bruijdegam vor sijn derde reijs met de twede dochter van Daniel Le Conte

'Mr. Johan Behn, who travelled with you to Leipzig, is groom for the third time to Daniel Le Conte’s second daughter' (letter 43, April 5, 1665)

(37) Men seijde vor desen dat met de jongfrou Rodenbergs verloeft was, so verleden jaer stirf bijden borgemester

'One said that he was previously engaged to maiden Rodenbergs, who died last year at the mayor's' (letter 2, dated June 8, 1664)

36 The letters by the four other correspondents comprise relative clauses, but without any relative particle so. For relativisation in the history of Dutch, see van der Wal (2002) and van der Horst (2008: 171-181, 377-383, 601-607, 829-834, 1113-1118, 1391-1397, 1681-1687). For relativisation in present-day Dutch dialects, see SAND (2005: vol1, 82-90). 
With inanimate antecedents, so functions both as subject and as object in mainly (but not exclusively) restrictive clauses. See (38) for so as subject in an embedded restrictive clause, (39) in a final restrictive and (40) in an embedded appositive clause.

(38) Hem manquert een pacxken so van Nantes soude hier gesonden sijn 'He misses a package that would have been sent from Nantes' (letter 12, August 24, 1664)

(39) Van weijnich enckelde blecken schrijft so onvercocht beschadigt en verrost waren

'You write about a few single iron sheets that were unsold, damaged and rusty’ (letter 30, January 11, 1665)

(40) De gecochte Barbades cattoenen so mijn X 17 costen, hebbe meest al weer vercocht

'I have already sold most of the Barbados cottons bought, which cost me X 17' (letter 12, August 24, 1664)

So as object appears in four types of relative clauses, which is illustrated by (41), an embedded restrictive clause, (42), a final restrictive clause, (43), an embedded appositive clause, and (44), a final appositive clause.

(41) Sal hun alles wel schrijven ende met eens bedancken vor alle courtegie so genoeten hebt 'I will write all to them and at the same time thank them for all the courtesy that you have received' (letter 34, February 8, 1665)

(42) Henrick Poorten hadde verleden weeck een van de hoijkens op, so hem gesonden hebt

'Last week Henrick Poorten was wearing one of the little hats that you sent him' (letter 27, December 21, 1664)

(43) met den doncker sendt met sijnen jongen een open doos so moeder aen naemp 'At darkness he sends an open box by his boy, which mother accepted' (letter 26, December 14, 1664)

(44) hij hadde een doos van u becomen, so mij wilde thuijs senden 'he had received a box from you, which he wanted to send me home' (letter 26, December 14, 1664) 
In sum, in Michiel Heusch's letters, so functions as an alternative for the Dutch relative pronouns die/dat both as subject and as object in four types of relative clauses. The total number of 41 instances comprise slightly more appositive than restricted relative clauses. In both types of clauses the embedded ones dominate: 16 embedded versus 6 final appositive clauses and 15 embedded versus 4 final restrictive clauses. Taking into account, however, both the animacy of the antecedent and the syntactic function of the relative particle so, particular patterns appear. In the case of animate antecedents, only appositive relative clauses are found and so functions only as subject. In the case of inanimate antecedents, so functions both as subject and, more frequently, as object in predominantly restrictive and appositive relative clauses. For frequency details, see Table 1.

Table 1: so as subject or object in different relative clauses.

\begin{tabular}{lrrrrr}
\hline $\begin{array}{l}\text { animacy } \\
\text { antecedent }\end{array}$ & $\begin{array}{r}\text { appositive } \\
\text { embedded }\end{array}$ & $\begin{array}{r}\text { appositive } \\
\text { final }\end{array}$ & $\begin{array}{r}\text { restrictive } \\
\text { embedded }\end{array}$ & $\begin{array}{r}\text { restrictive } \\
\text { final }\end{array}$ & Total \\
\hline A - so subject & 11 & 4 & 0 & 0 & 15 \\
A - so object & 0 & 0 & 0 & 0 & 0 \\
inA - so subject & 3 & 0 & 6 & 1 & 10 \\
inA - so object & 2 & 2 & 9 & 3 & 16 \\
Total & 16 & 6 & 15 & 4 & 41 \\
\hline
\end{tabular}

Ebert's observation (1993: 447) for German so, which would occur mainly in embedded restrictive relative clauses, therefore, does not apply to Heusch senior's usage of so in Dutch.

Some interesting issues still remain such as whether a particular explanation for the usage of German so would explain Heusch senior's usage of so in his Dutch letters. An advice to vary in conjunctive relative clauses was given by a.o. the contemporary grammarian Schottelius (1612-1676) (Ebert 1986: 163). The Dutch usage, however, does not appear to be determined by the need to avoid repetition in conjunctive relative clauses, as only a single instance of such a clause occurs:

(41) Detlof sijn soen, so naest den Baars woont in grootmoeders woningen, die ons het houdt pleech te setten, is mede overleden

'Detlof's son, who lives next to the Baars in grandmother's houses, who used to stack wood for us, also died' (letter 14, September 14, 1664) 
In order to establish whether the Dutch usage in four types of relative clauses extends the suggested contemporary German usage of so (Ebert 1993), a more detailed comparison with late-seventeenth-century German texts would be needed. This is, however, beyond the scope of this article. Most importantly, the occurrence of the relative particle so in the Heusch correspondence has been shown to be a clear case of adopting a German supraregional feature in written Dutch.

\section{Conclusions}

The events of the Heusch family illustrate how wealthy merchants who were forced into migration succeeded in achieving an influential position in the city of Hamburg. The historical and sociolinguistic context sheds light on the confiscated Heusch correspondence which reveals linguistic practices. The male family members learned the languages needed for their commercial activities: Italian and French, both in spoken and written form. All relatives, second and third generation migrants, belonged to a vibrant community of Dutch-speaking people with shared roots and own institutions. It is, therefore, not surprising that they still appear to have a good command of written Dutch. It is both the characteristics of their Dutch usage and interference phenomena due to the language contact setting that we examined.

Michiel Heusch's consistent ellipsis of the second person pronoun and his irregular third person pronoun ellipsis appeared to be prominent features in the correspondence and therefore deserved attention. This extension of the first person pronoun ellipsis, a familiar epistolary feature, could be considered a phenomenon of conversational deletion in his weekly written contact with his son. This phenomenon does not occur in letters by the other relatives or in other private correspondence with which we are familiar. So far it seems an individual characteristic in Heusch senior's letters. Whether the extension of the first person pronoun ellipsis is to be found in an elaborate corpus of contemporary business letters remains a suggestion for further research.

In the usage of our Dutch migrants abroad, variation is found not only in the case of ellipsis, but also in forms of address: usage of ghij/ghy 'you' by the two female letter writers and of $u l$ by the two male writers, which are both familiar variants in a non-migrant Dutch setting. Other inter-individual variation between the five letter writers was found in epistolary formulae. This variation and the formulaic variants do not deviate from the late-seventeenth-century Dutch in private letters of non-migrants from the Letters as Loot corpus. Moreover, this variation in usage illustrates a still good command of varied written Dutch. 
Whether and to which degree this varied written Dutch was influenced by the language contact setting, was our second issue to be addressed.

The letter writers participated considerably in the Hamburgian society as is most clearly shown by Heusch senior's position. They lived in a language contact setting of Low German speakers and must have known written High German. The preserved correspondence appears to reveal effects of this language contact. The relatively brief letters by mother and sister contain each only a single sign of interference: the Low Dutch pinghsten and the verb worden, indicating future, which is a German feature. All other instances of lexical interference are found in the letters written by the main correspondent, Heusch senior. It is his letters that also show two different interference phenomena: Low German influence of the reflexive pronoun sick and the relative particle pattern of supraregional German so. Both phenomena do not occur in the less elaborate letters by the four other family members. Furthermore, we note that we do not find instances of codeswitching in any of the letters. ${ }^{37}$

The Heusch correspondence testifies to the survival of Dutch in a Low German mercantile environment. Moreover, this case illustrates that survival of a native language largely depends on the context - in this case the Hamburg population with a considerable number of inhabitants with Flemish roots. There is more to it than this. Various scenarios of language contact exist and scholars try to develop typologies of language contact in times past (cf. Rutten et al. 2017: 4). In order to achieve this, in-depth research of the experiences of historical individuals and their daily practices is needed. The present sociohistorical linguistic analysis of the Heusch letters gives us the opportunity to gain a view of such linguistic practices in the past and allows us to contribute to a historical sociolinguistic theory of language contact.

\section{References}

Ágel, Vilmos. 2010. + /-Wandel. Am Beispiel der Relativpartikeln so und wo. In Dagmar Bittner \& Livio Gaeta (eds.), Kodierungstechniken im Wandel: Das Zusammenspiel von Analytik und Synthese im Gegenwartsdeutschen Linguistik - Impulse \& Tendenzen 34, 199-222. Berlin \& New York: de Gruyter.

Asaert, Gustaaf. 2010. 1585 De val van Antwerpen en de uittocht van Vlamingen en Brabanders [The fall of Antwerp and the exodus of Flemish and Brabantian people]. Tielt: Lannoo.

37 The only instance of a German phrase is the following literal quote: daerop sijn eijgen swager Becker plech te seggen mijn swager kauft Landt gueter mit es maul 'his own brother-in-law Becker used to say: my brother-in-law buys estates with his mouth (= talking, boasting)' (letter 12, dated August 24, 1664; Heusch senior). 
Barbiers, Sjef, Hans Bennis, Gunther De Vogelaer, Magda Devos \& Margreet van der Ham. 2005. $S A N D=$ Syntactische Atlas van de Nederlandse Dialecten [Syntactic atlas of Dutch dialects]. vol. 1. Amsterdam: Amsterdam University Press.

Baumann, Wolf-Rüdiger. 1990. The merchant adventurers and the continental cloth trade (1560s-1620s). Berlin \& New York: W. de Gruyter.

Behaghel, Otto. 1928. Deutsche Syntax: Eine geschichtliche Darstellung III. Heidelberg: Winters. Boyce-Hendriks, Jennifer. 1998. Immigration and linguistic change: A socio-historical linguistic study of the effect of German and Southern Dutch immigration on the development of the Northern Dutch vernacular in sixteenth/seventeenth century Holland. Madison, WI: University of Wisconsin dissertation.

Braunmüller, Kurt. 1997. Communication strategies in the area of the Hanseatic League: The approach of semi-communication. Multilingua 16. 365-373.

Braunmüller, Kurt. 2007. Receptive multilingualism in Northern Europe in the middle ages: A description of a scenario. In Jan D. Ten Thije \& Ludger Zeevaert (eds.), Receptive multilingualism: Linguistic analyses, language policies and didactic concepts, 25-47. Amsterdam \& Philadelphia: John Benjamins.

Braunmüller, Kurt. 2013. Communication based on receptive multilingualism: Advantages and disadvantages. International Journal of Multilingualism 10. 214-223.

Burke, Peter. 2004. Languages and communities in Early Modern Europe. Cambridge: Cambridge University Press.

Dal, Ingerid. 2014 [1962]. Kurze deutsche Syntax auf historischer Grundlage. 2nd edn. Tübingen: Niemeyer.

Ebert, Robert Peter. 1986. Historische Syntax des Deutschen II. 1350-1750. Bern: Lang.

Ebert, Robert Peter. 1993. Syntax. In Oskar Reichmann \& Klaus-Peter Wegera (eds.), Frühneuhochdeutsche Grammatik, 313-484. Tübingen: Niemeyer.

Elspaß, Stephan. 2012a. The use of private letters and diaries in sociolinguistic investigation. In Juan Manuel Hernández-Campoy \& Juan Camilo Conde-Silvestre (eds.), Handbook of historical sociolinguistics, 156-169. Malden, MA \& Oxford: Wiley-Blackwell.

Elspaß, Stephan. 2012b. Between linguistic creativity and formulaic restriction: Crosslinguistic perspectives on nineteenth-century century lower class writers' private letters. In Marina Dossena \& Gabriella Del Lungo Camiciotti (eds.), Letter writing in Late Modern Europe, 45-64. Amsterdam \& Philadelphia: John Benjamins.

Elspaß, Stephan \& Doris Stolberg. 2014. "Ich bit eich in got willen sich mir doch gelt das ich kann leben". German letters in the prize papers corpus - Preliminary linguistic analyses. Paper presented at the conference All at Sea: The Prize Papers as a source for a global microhistory, The National Archives (Kew), 6-8 October 2014.

Fürth, Hermann Ariovist von. 1890. Beiträge und Material zur Geschichte der Aachener PatrizierFamilien. vol. 1. Aachen: Verlag der Cremerschen Buchhandlung.

Goss, Emily L. 2002. Negotiated language change in Early Modern Holland. Immigration and linguistic variation in the Hague (1600-1670) Madison, WI: University of Wisconsin dissertation.

Handelskammer Hamburg. 2015. Wir handeln für Hamburg. 350 Jahre Handelskammer Hamburg. Kiel \& Hamburg: Wachholtz Verlag \& Murmann Publishers.

van der Horst, Joop M. 2008. Geschiedenis van de Nederlandse syntaxis [History of Dutch syntax]. 2 vols. Louvain: Leuven University Press.

Joby, Christopher. 2015. The Dutch language in Britain (1550-1702): A social history of the use of Dutch in Early Modern Britain. Leiden \& Boston: Brill. 
Johnson, John Graver, Bernard Berenson \& Wilhelm Reinhold Valentiner. 1913. Catalogue of a collection of paintings and some art objects: Flemish and Dutch painters. Philadelphia: John G. Johnson.

Krol, Hetty. 2011. Michiel Heusch Jr.: On a business trip in Italy. In Monthly Letters of the Letters as Loot programme, August/September 2011. https://www.universiteitleiden.nl/binaries/ content/assets/geesteswetenschappen/onderzoeksprojecten/letters-as-loot/monthly-let ter-august-september-2011.pdf

Kühl, Karoline \& Kurt Braunmüller. 2014. Linguistic stability and divergence: An extended perspective on language contact. In Kurt Braunmüller, Steffen Höder \& Karoline Kühl (eds.), Stability and divergence in language contact: Factors and mechanisms, 13-38. Amsterdam \& Philadelphia: John Benjamins.

Lindberg, Erik. 2008. The rise of Hamburg as a global marketplace in the seventeenth century: A comparative political economy perspective. Comparative Studies in Society and History 50(3). 641-662.

Lodge, Anthony. 2014. Jacques-Louis Ménétra and his experience of the langue d'oc. In Gijsbert Rutten, Rik Vosters \& Wim Vandenbussche (eds.), Norms and usage in language history, 1600-1900: A sociolinguistic and comparative perspective, 201-221. Amsterdam \& Philadelphia: John Benjamins.

Merck, Ernst (ed.). 1856. Briefe des Hamburgischen Buergermeister Johann Schulte Lt. An seinen in Lissabon etablierten Sohn Johann Schulte, geschrieben in den Jahren 1680-1685. Hamburg: Perthes-Besser \& Mauke.

Nobels, Judith. 2013. (Extra)Ordinary letters: A view from below on seventeenth-century Dutch. Utrecht: LOT. University of Leiden dissertation.

Poettering, Jorun. 2013. Handel, Nation und Religion: Kaufleute zwischen Hamburg und Portugal im 17. Jahrhundert. Göttingen: Vandenhoeck \& Ruprecht.

Reißmann, Martin. 1975. Die hamburgische Kaufmannschaft des 17. Jahrhunderts in sozialgeschichtlicher Sicht. Hamburg: Hans Christians Verlag.

Rutten, Gijsbert, Joseph Salmons, Wim Vandenbussche \& Rik Vosters. 2017. Unraveling multilingualism in times past. Sociolinguistica: International Yearbook of European Sociolinguistics 31. 1-12.

Rutten, Gijsbert \& Marijke van der Wal. 2014. Letters as loot: A sociolinguistic approach to seventeenth- and eighteenth-century Dutch. Amsterdam \& Philadelphia: John Benjamins.

Schaser, Angelika. 1995. Städtische Fremdenpolitik im Deutschland der Frühen Neuzeit. In Alexander Demandt (ed.), Mit Fremden leben: Eine Kulturgeschichte von der Antike bis zur Gegenwart, 137-157, 270-278. München: C.H. Beck Verlag.

Schendl, Herbert. 2012. Multilingualism, code-switching, and language contact in historical sociolinguistics. In Juan Manuel Hernández-Campoy \& Juan Camilo Conde-Silvestre (eds.), The handbook of historical sociolinguistics, 520-533. Malden \& Oxford: Wiley-Blackwell.

Schneider, Edgar. 2013. Investigating historical variation and change in written documents: New perspectives. In J.K. Chambers \& Natalie Schilling (eds.), The handbook of language variation and change, 2nd edn. 57-81. Malden \& Oxford: Wiley-Blackwell.

Thrasher, Randolph H. Jr 1974. Shouldn't ignore these strings: A study of conversational deletion. Ann Arbor: University of Michigan dissertation.

Trudgill, Peter. 2013. The role of Dutch in the development of East Anglian English. Taal \& Tongval 65. 11-22.

Uppenkamp, Barbara. 2015. Gilles Coignet: A migrant painter from Antwerp and his Hamburg career. De Zeventiende Eeuw [The Seventeenth Century] 31. 55-77. 
Van Roosbroeck, Robert. 1968. Emigranten: Nederlandse vluchtelingen in Duitsland (15501600) [Emigrants: Netherlandish refugees in Germany (1550-1600)]. Louvain: Davidsfonds. Vogl, Ulrike. 2012. Multilingualism in a standard language culture. In Matthias Hüning, Ulrike Vogl \& Olivier Moliner (eds.), Standard languages and multilingualism in European history, 1-42. Amsterdam \& Philadelphia: John Benjamins.

van der Wal, Marijke J. 1992. Dialect and standard language in the past: The rise of the Dutch standard language in the sixteenth and seventeenth centuries. In J.A. Van Leuvensteijn \& Johannes B Berns (eds.), Dialect and standard language, 119-129. Amsterdam, Oxford, New York \& Tokyo: Koninklijke Nederlandse Akademie van Wetenschappen Verhandelingen, Afd. Letterkunde, Nieuwe Reeks, deel 150.

van der Wal, Marijke J. 2002. Relativisation in the history of Dutch: Major shift or lexical change? In Patricia Poussa (ed.), Relativisation on the North Sea Littoral, 27-35. München: Lincom. van der Wal, Marijke 2006. Onvoltooid verleden tijd. Witte plekken in de taalgeschiedenis [Imperfect past time. Blank spots in language history], inaugural lecture 17 November 2006. Amsterdam: Koninklijke Nederlandse Academie van Wetenschappen

van der Wal, Marijke 2016. Crossing linguistic boundaries: Migration and multilingualism in Early and Late Modern times. Key note paper presented at the HiSoN Conference Historical sociolinguistics and socio-cultural change, University of Helsinki, 10-11 March 2016.

van der Wal, Marijke \& Gijsbert Rutten. 2016. At the cross-roads. Orality and literacy in early and Late Modern Dutch private letters. In Ann-Catrine Edlund, T.G. Ashplant \& Anna Kuismin (eds.), Reading and writing from below: Exploring the margins of modernity, 197-214. Umeå: Umeå University \& Royal Skyttean Society.

van der Wal, Marijke, Gijsbert Rutten \& Tanja Simons. 2012. Letters as loot. Confiscated letters filling major gaps in the history of Dutch. In Marina Dossena \& Gabriella Del Lungo Camiciotti (eds.), Letter writing in Late Modern Europe, 139-161. Amsterdam \& Philadelphia: John Benjamins.

Waley, Joachim. 2002. Religious toleration and social change in Hamburg. 1529-1819. Cambridge: Cambridge University Press.

\section{Websites}

The 'Brieven als Buit/Letters as Loot' website, both in Dutch and in English: https://www.universiteitleiden.nl/onderzoek/onderzoeksprojecten/geesteswe tenschappen/brieven-als-buit; https://www.universiteitleiden.nl/en/research/ research-projects/humanities/letters-as-loot.-towards-a-non-standard-view-onthe-history-of-dutch.

http://brievenalsbuit.inl.nl.

The Letters as Loot/Brieven als Buit corpus. Leiden University. Compiled by Marijke van der Wal (Programme leader), Gijsbert Rutten, Judith Nobels and Tanja Simons, with the assistance of volunteers of the Leiden-based Wikiscripta Neerlandica transcription project, and lemmatised, tagged and provided with search facilities by the Institute for Dutch Lexicology (INL). 2013, second release 2015. 